\title{
Applications of Nanoscale Polypyrrole Proton Exchange Membrane in Microbial Fuel Cells
}

\author{
Li-ping $\mathrm{Fan}^{1}{ }^{*}$, Tian Gao ${ }^{2}$ \\ ${ }^{1}$ College of Information Engineering, Shenyang University of Chemical Technology, Shenyang, \\ 110142 China \\ ${ }^{2}$ College of Environmental and Softy Engineering, Shenyang University of Chemical Technology, \\ Shenyang 110142 China \\ *E-mail: flpsd@163.com
}

doi: $10.20964 / 2019.01 .41$

Received: 25 September 2018 / Accepted: 2 November 2018 / Published: 30 November 2018

\begin{abstract}
Using simulated syrup wastewater and lake silt as substrates, a microbial fuel cell power generation system was set up, the effect of nanoscale polypyrrole proton exchange membrane on the performance of microbial fuel cells was studied. Firstly, using the Nafion membrane MFC and nanoscale $\mathrm{TiO}_{2} / \mathrm{SiO}_{2}$ proton membrane MFC as comparisons; secondly, by using the methods of surface polymerization and internal polymerization, $\mathrm{FeCl}_{3}$ and $\mathrm{H}_{2} \mathrm{O}_{2}$ were used as initiators, polypyrrole proton exchange membrane and nanoscale polypyrrole proton exchange membrane were prepared, and the performances of several kinds of microbial fuel cells with different membrane were tested and compared. The result shows that, the performance of MFC with nanoscale polypyrrole proton exchange membrane is the best. When internal polymerized nanoscale polypyrrole proton exchange membrane prepared by using the $\mathrm{FeCl}_{3}$ as initiator was used as the separator of MFC, the steady output voltage is $17.3 \mathrm{mV}$, COD removal is 25.24 $\%$, and the water uptake of the membrane is $64.37 \%$; when surface polymerized nanoscale polypyrrole proton exchange membrane was used as the separator of MFC, the state voltage is $14.4 \mathrm{mV}$, COD removal is $36.55 \%$, and the water uptake of the membrane is $54.18 \%$. And when $\mathrm{H}_{2} \mathrm{O}_{2}$ was used as initiator, the steady voltage of MFC with internal polymerized nanoscale polypyrrole proton exchange membrane is $9.2 \mathrm{mV}$, COD removal is $19.39 \%$, and the water uptake of the membrane is $41.59 \%$; the steady voltage of MFC with surface polymerized nanoscale polypyrrole proton exchange membrane is $8.4 \mathrm{mV}$, COD removal is $29.38 \%$, and the water uptake of the membrane is $32.39 \%$. The nanoscale polypyrrole proton exchange membrane improved the performance of MFC evidently.
\end{abstract}

Keywords: microbial fuel cell; proton exchange membrane; surface polymerization; internal polymerization 


\section{FULL TEXT}

(C) 2019 The Authors. Published by ESG (www.electrochemsci.org). This article is an open access article distributed under the terms and conditions of the Creative Commons Attribution license (http://creativecommons.org/licenses/by/4.0/). 